\title{
AKUMULACIJA SUNČEVE ENERGIJE U OBITELJSKIM PASIVNIM KUĆAMA
}

\section{Željko Koški}

Sveučilište J. J. Strossmayera u Osijeku, Građevinski fakultet Osijek, prof.dr.sc.

\section{Gorana Zorić}

Sveučilište J. J. Strossmayera u Osijeku, Građevinski fakultet Osijek, student

Sažetak: Članak je potaknut potrebom podizanja razine energetske učinkovitosti i uporabe obnovljive energije Sunca u obiteljskim kućama. S ciljem boljeg razumijevanja korištenja Sunčeve energije, članak prezentira značaj fizikalne pojave akumulacije topline u elementima zgrada. Osim utvrđivanja razlike u aktivnom i pasivnom korištenju Sunčeve energije u zgradama, prezentirani su i osnovni elementi koji definiraju standardizirane karakteristike pasivnih kuća. Definirana je akumulacija topline u građevinskim elementima, kao i elementi koji na nju najviše utječu. $U$ drugom dijelu članka su proanalizirani načini prihvata i akumuliranja Sunčeve energije $u$ pasivnim obiteljskim kućama s pripadajućim primjerima.

Ključne riječi: energetska efikasnost u zgradama, akumulacija topline, Sunčeva energija, pasivne kuće

\section{SOLAR ENERGY ACCUMULATION IN FAMILY PASSIVE HOUSES}

Abstract: The article is induced by the need for increasing energy efficiency and sun energy use in family houses. Aiming to better understanding of sun energy use, the article discusses the importance of heat accumulation in building elements. Apart from determining the difference between active and passive sun energy use in buildings, the article presents some basic elements which define standard characteristics of passive houses. Heat accumulation in building elements is defined, as well as elements with most influence to heat accumulation. The second part of the article deals with the types of sun energy accumulation in passive houses and related examples.

Key words: energy efficiency in buildings, heat accumulation, sun energy, passive houses 


\section{Uvod}

Osiguranje dovoljnih količina jeftine energije i zaštita čovjekovog okoliša temeljni su zahtjevi za ostvarenje održivog razvitka naše civilizacije. Istraživanja i usavršavanja tehnologija za uporabu obnovljivih izvora energije provode se u mnogim područjima ljudskog djelovanja pa tako i u graditeljstvu.

Izgradnja novih zgrada i boravak ljudi u njima kao temeljna ljudska potreba na početku 21. stoljeća, imaju vrlo kompleksne i važne zahtjeve koji će značajno utjecati na opći razvitak. Europska Unija u posljednja dva desetljeća, $s$ ciljem sigurnije opskrbe energijom, poduzima sveobuhvatne mjere protiv neracionalne potrošnje energije i posljedičnog zagađenja atmosfere otpadnim plinovima (emisija $\mathrm{CO}_{2}$ ).

Prosječno loše stanje postojećih zgrada u pogledu ostvarivanja kvalitetnog toplinskog komfora i energetske učinkovitosti, podupire procjenu da se postojeća i buduća izgradnja zgrada u Republici Hrvatskoj može značajno unaprijediti kako bi se zadovoljile suvremene arhitektonsko-energetske i biološko-ekološke potrebe ljudi, u skladu sa standardima Europske Unije. Racionalna potrošnja energije i postizanje primjerene energetske učinkovitosti u zgradama, što uključuje primjenu i korištenje obnovljivih izvora energije, značajno bi doprinijelo općem gospodarskom i prostornom razvitku.

\section{Sunčevo zračenje kao obnovljivi izvor energije}

Potencijalno najveći izvor obnovljive energije je Sunce, užarena plinovita kugla čije zračenje dolazi na Zemlju. Sunčeva energija je sigurna, neprekidna i najmanje štetna za okoliš. Temelj je života na Zemlji i stalni pratilac razvoja ljudskog roda. Smatra se da su ovaj izvor energije ljudi koristili prvo instinktivno, a zatim svjesno. Prvo su je počeli koristiti za potpalu vatre, zatim je bila neophodna za konzerviranje hrane, za sušenje životinjske kože itd. Za Arhimeda se, na primjer, tvrdi da je 214. g.p.K., kad su Rimljani opsjedali Sirakuzu, uz pomoć zrcala i Sunca zapalio neprijateljske brodove. U Plutarhovim spisima može se naći podatak da su vestalinke u vrijeme Nume Pompilija (714-671 g.p.K.) za paljenje vatre koristile konusne metalne plitice kojima su reflektirale Sunčeve zrake u jednu točku1.

Današnja tehnologija energiju Sunca primjenjuje u najrazličitijim oblicima, od solarne vrtne rasvjete do automobila na solarni pogon. Suvremeno društvo prepoznalo je brojne prednosti uporabe energije Sunca: smanjenje ovisnosti o fosilnim gorivima, poboljšanje kakvoće zraka i smanjenje emisija stakleničkih plinova.

Količinu Sunčeve energije koja stiže do Zemlje određujemo po intenzitetu Sunčevih zraka i dužini Sunčevih perioda tijekom godine, pri čemu je godišnje dozračena energija veća oko 15000 puta od ukupnih svjetskih potreba. Za vrijeme sunčanog dana, prosječno na svaki kvadratni metar osunčane površine pristiže energija od 1000 W. U Republici Hrvatskoj godišnje djelovanje Sunca na horizontalnu plohu iznosi $1200-1600 \mathrm{kWh} / \mathrm{m}^{2}$, ovisno radi li se o kontinentalnom ili primorskom dijelu². Od toga se $75 \%$ ostvari u toplijoj polovici godine (od početka travnja do kraja rujna).

Klimatski preduvjeti za korištenje Sunčevog zračenja u osječkoj regiji bolji su od većine europskih zemalja, što uključuje prosječno oko 1900 sunčanih sati godišnje, od čega preko 600 sati u sezoni grijanja zgrada ${ }^{3}$.

Budući da je prividni put Sunca preko nebeskog svoda u hladnijem dijelu godine kraći u odnosu na ljetne mjesece, a upadni kut znatno manji, mijenja se i najpovoljniji kut pod kojim je potrebno postaviti kolektor da bi se postigle najveće vrijednosti prikupljenog zračenja.

U području graditeljstva, energija Sunca može se iskorištavati aktivno i pasivno. Aktivno korištenje Sunčevog zračenja podrazumijeva njegovo izravno pretvaranje u toplinsku ili električnu energiju. To pretvaranje vrši se pomoću različitih uređaja, a najčešći su solarni kolektori za stvaranje toplinske energije i fotonaponski paneli za stvaranje električne energije.

Korištenje Sunčeve energije u zgradama na pasivan način ne traži nikakve nove i komplicirane tehnologije. Sustav funkcionira tako da se pomoću dobro ukomponiranih tradicionalnih materijala za građenje, kao što su beton, kamen, staklo, drvo i metal, maksimalno iskoristi snaga vječnog izvora topline Sunca.

\footnotetext{
1 izvor podataka: http://www.scribd.com/doc/15507540/energija

2 izvor podataka: http://vjetar.bloger.hr/post/sunceva-energija-/3410823.aspx

3 izvor podataka: Prostorni plan Zajednice općina Osijek 2000. ; Osijek 1985.
} 
Temeljni princip pasivnog korištenja Sunčeve energije sastoji se u tome da se zgrada otvara prema Suncu i koristi njegovu energiju. Čim Sunca nestane i čim vanjski uvjeti postanu nepovoljni, treba se zaštititi od gubitaka topline zatvaranjem prema okolini.

Realizacija ovih nimalo jednostavnih zahtjeva nalazi se u sveobuhvatnom proučavanju fizikalnih procesa koji se odvijaju nakon prodora Sunčevih zraka u unutrašnjost zgrade. U svakom projektu treba zasebno analizirati što će se dešavati s energijom Sunca koja uđe u zgradu i elemente zgrade prilagoditi tako da se pasivno korištenje Sunčeve energije provede na praktično izvodiv i ekonomski prihvatljiv način.

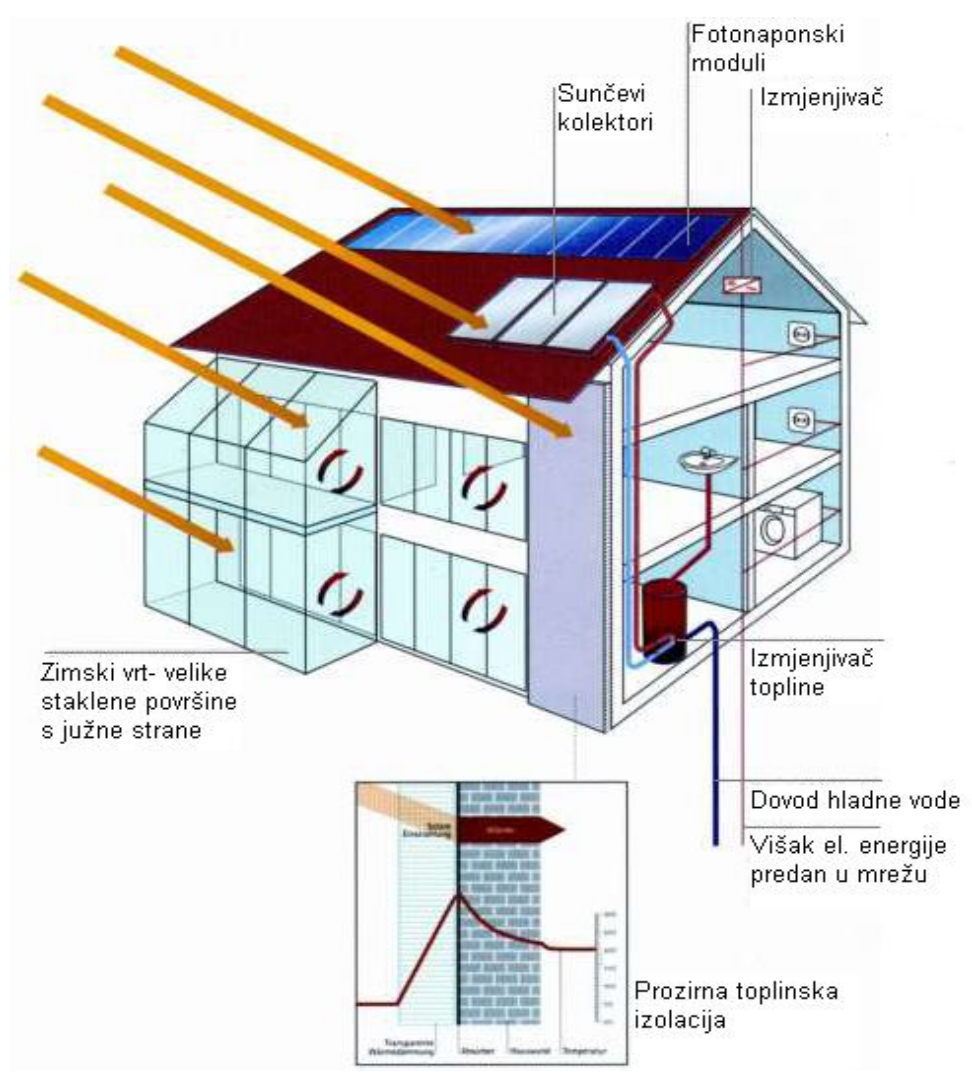

Slika 1 - Aktivno i pasivno korištenje Sunčeve energije u zgradama

Zadatak pasivnih solarnih sustava je prihvatiti, odnosno akumulirati što više Sunčeve energije u elementima zgrada kada je to korisno u sezoni grijanja, a da se prostorije ne pregriju. Isto tako treba se maksimalno zaštititi od jakog djelovanja Sunca u ljetnom periodu, jer će ono stvoriti prekomjerno zagrijavanje prostorija.

\section{Akumulacija topline u elementima zgrada}

Općenito, akumulacija topline je svojstvo građevinskih materijala da mogu prihvatiti dovedenu im toplinu, u sebi je akumulirati (sačuvati) i kod hlađenja okoline ponovo je predavati okolini.

Ova karakteristika vrlo je bitna u zgradama tijekom zimskog perioda kada grijanje ne radi kontinuirano cijeli dan, već se u pravilu prekida preko noći. Akumulirana toplinska energija omogućuje da se temperatura u prostorijama bitno ne smanji tijekom noći.

Količina toplinske energije koja se akumulira u građevinskom elementu ovisi najviše o razlici temperatura elementa i okolnog zraka, te o specifičnom toplinskom kapacitetu i masi elementa.

Koeficijent akumulacije topline (W) je količina topline koju građevinski element akumulira po jedinici površine, za jediničnu razliku temperatura unutarnjeg i vanjskog zraka, kada je postignuto stacionarno stanje ${ }^{4}$.

\footnotetext{
${ }^{4}$ Šimetin, V.: Građevinska fizika, GI Fakultet građevinskih znanosti Sveučilišta u Zagrebu, Zagreb1983. str.41-42.
} 


$$
\begin{aligned}
& W=d_{1}{ }^{*} G_{1}{ }^{*} C_{1}\left(1 / \alpha_{e}+d_{1} / 2 \lambda_{1}\right)+d_{2}{ }^{*} G_{2}{ }^{*} C_{2}\left(1 / \alpha_{e}+d_{1} / \lambda_{1}+d_{2} / 2 \lambda_{2}\right)+\ldots . . \\
&\left.\ldots \ldots .+d_{n}{ }^{*} G_{n}{ }^{*} C_{n}\left(1 / \alpha_{e}+d_{1} / \lambda_{1}+d_{2} / \lambda_{2}+\ldots \ldots . .+d_{n} / 2 \lambda_{n}\right)\right]\left(k J / m^{2} K\right)
\end{aligned}
$$

$\mathrm{U}=$ koeficijent prolaska topline $\left(\mathrm{W} / \mathrm{m}^{2} \mathrm{~K}\right)$

$\alpha_{e}=$ koeficijent prijelaza topline $\left(\mathrm{W} / \mathrm{m}^{2} \mathrm{~K}\right)$

$\mathrm{d}=$ debljina pojedinog sloja građevinskog elementa $(\mathrm{m})$
$\mathrm{G}=$ specifična težina $(\mathrm{kg} / \mathrm{m} 3)$

$\mathrm{c}=$ specifični toplinski kapacitet $(\mathrm{J} / \mathrm{kgK})$

$\lambda=$ koeficijent toplinske provodljivosti (W/mK)

Da bi se ostvarili što bolji preduvjeti za akumulaciju topline u građevinskim elementima, potrebno je materijale $s$ većom specifičnom težinom u višeslojnim pregradama postaviti s unutrašnje, tople strane. To znači da toplinsku izolaciju obodnih konstrukcija uvijek treba postavljati s vanjske strane. Ovaj način postave toplinske izolacije u zgradama nužno je ostvariti, jer nepostojanje akumulirane topline u obodnim konstrukcijama loše se odražava na ostvarivanje toplinskog komfora i racionalnu potrošnju energije.
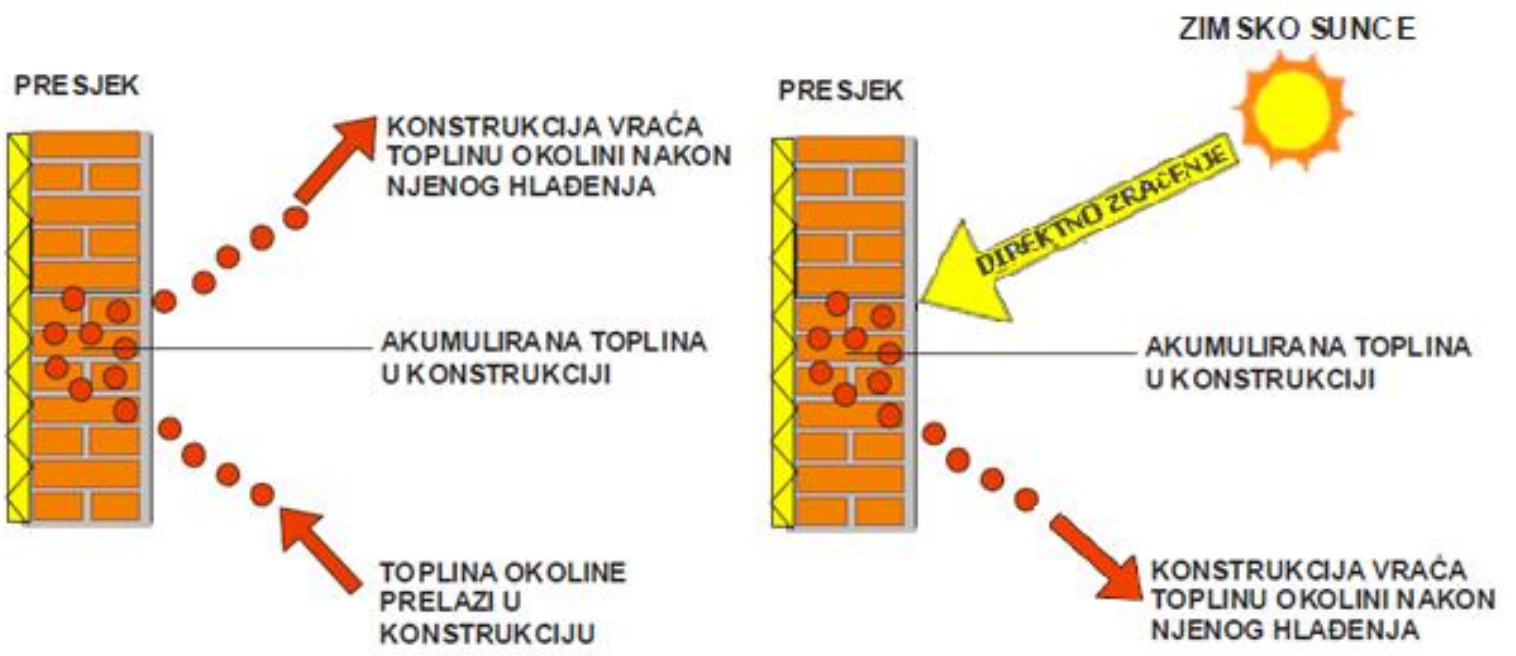

\section{Slika 2 - Izvori akumulacije topline u građevinskim elementima}

Sunčevo zračenje koje pada na jedinicu površine nekog građevinskog elementa razlaže se u nekoliko dijelova. Omjer tih dijelova ovisi o koeficijentu apsorpcije, refleksije i transparentnosti površine građevinskog elementa na koji pada Sunčevo zračenje. Količina apsorbiranog kratkovalnog Sunčevog zračenja ovisi najviše o boji površine građevinskog elementa. Svijetle boje više reflektiraju Sunčevo zračenje, a tamne površine puno više apsorbiraju Sunčevu energiju. Koeficijent apsorpcije za bijelu boju je 20-30 \%, a za crnu 90-100 \% 5 .

\section{Pasivna kuća}

Glavna karakteristika pasivnih kuća je maksimalno korištenje Sunca kao izvora energije za ostvarivanje kvalitetnog toplinskog komfora. Kroz povijest izgradnje ljudskih nastambi možemo pratiti različito oblikovanje i prilagodbe kuća kako bi se iskoristilo energiju Sunca.

Takav primjer predstavlja i Sokratova kuća (Sokrat - grčki filozof, 470.-399. pr.n.e.)6. Kuća je imala tlocrt trapeznog oblika s bazom orijentiranom prema jugu, masivnog vanjskog zida od kamena, s minimalnim otvorima za provjetravanje na pročeljima. Trijem je bio otvoren prema jugu, što je omogućavalo da Sunčeve zrake ljeti gotovo uopće ne ulaze u prostor, a zimi, kada zrake Sunca padaju niže, griju cijeli prostor (slika 3).

\footnotetext{
${ }^{5}$ Šimetin, V.: Građevinska fizika, GI Fakultet građevinskih znanosti Sveučilišta u Zagrebu, Zagreb1983. str.92.

6 izvor podataka: http://www.korak.com.hr/sos.php?id_sos=318\&vijestiPage=9
} 


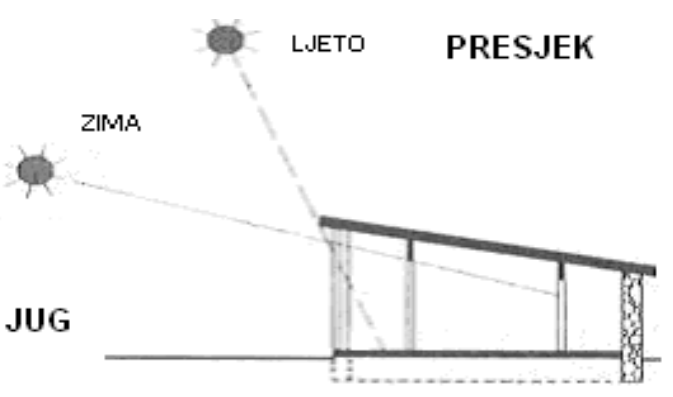

Slika 3 - Sokratova kuća trapeznog oblika s tlocrtom orijentiranom prema jugu

Elementi pasivnih kuća razvijali su se usporedno s napredovanjem tehnologije gradnje, a posebno u 20. stoljeću. Danas prihvaćeni naziv pasivna kuća razvio je u Njemačkoj dr.sc. Wolfgang Feist (Passivhaus Institut)7. Probni projekt koncepta pasivne kuće izgrađen je u Darmstadtu 1991. godine, a u praksi se pokazao kao novi, međunarodno prihvaćeni standard za izgradnju pasivnih kuća.

Pasivna kuća predstavlja objekt u kojem je tijekom cijele godine prisutna ugodna temperatura. Naglasak je na riječi pasivno, što u praksi znači da toplinske potrebe kuće treba zadovoljiti bez trošenja ogrjeva, samo uporabom Sunčeve topline i promišljenim iskorištenjem toplijeg ili hladnijeg zračnog strujanja. Osnova za udobnost takvih kuća je i izvedba građevinskih elemenata i materijala koji bi trebali biti estetski, oblikovno i funkcionalno povezani. Takva kvaliteta građenja utječe na ukupnu energetsku potrošnju cijele godine.

Pasivna kuća nije nova tehnologija gradnje, već dosljedno izvedena kuća koja troši vrlo malo energije. Zgrada i njezina funkcija ostaju potpuno tradicionalne, a nema ograničenja ni u oblikovanju. To je zgrada $s$ godišnjom potrebnom toplinom za grijanje do $15 \mathrm{kWh} / \mathrm{m}^{2} a$. Nema uobičajeni sustav za grijanje ili uređaj za klimu. Potrebna toplina za grijanje dovodi se preko uređaja za prozračivanje koji istodobno osigurava i vraćanje topline iskorištenog zraka (grijanje toplim zrakom). Konstrukcija zgrade mora biti izvedena bez toplinskih mostova. Mora zadovoljiti određenu zrakonepropusnost omotača zgrade. Zajednička potrošnja primarne energije je najviše 120 $\mathrm{kWh} / \mathrm{m}^{2} \mathrm{a}^{8}$

Pasivna kuća utroši i do $80 \%$ manje energije u usporedbi s klasičnim građevinama, a njezina učinkovitost bazirana je na vrlo dobrom i kvalitetno izvedenom sloju toplinske izolacije, zatim kvalitetnim prozorima i vratima koji sprječavaju gubitak topline, sustavu strujanja zraka koji osim prozračivanja osigurava dodatno čuvanje energije, te korištenju Sunčeve energije.

Teorija akumuliranja, odnosno pohranjivanja topline iz Sunčevog zračenja u elementima zgrada, razlikuje tri osnovna načina:

A) direktan zahvat Sunčevog zračenja kao princip izvedbe staklenih površina na južnoj strani kuće, kako bi propustile što veću količinu Sunčevog zračenja;

B) trombov zid je konstrukcija tamno obojenog zida sa staklenom plohom na južnoj strani;

C) staklenik na južnoj strani kuće.

\section{Direktan zahvat Sunčevog zračenja}

Direktan zahvat Sunčevog zračenja je najjednostavniji oblik pasivne tehnike grijanja prostora. Sunčeva svjetlost direktno ulazi kroz prozore na južnoj strani kuće, izravno zagrijava prostor, čak i za oblačnih dana. Tako se toplina akumulira (pohrani) u konstrukciji i elementima zgrade, a tijekom noći vraća se okolini. Prozori su postavljeni na način da upijaju zračenje niskog zimskog Sunca. Prozori tako izloženi Suncu koriste $60-75 \%$ Sunčeve energije (slika 4).

\footnotetext{
7 Zbašnik-Senegačnik M. : Pasivna kuća, SUN ARH d.o.o. Zagreb 2009. str. 25.

${ }^{8}$ Zbašnik-Senegačnik M. : Pasivna kuća, SUN ARH d.o.o. Zagreb 2009. str. 24.
} 

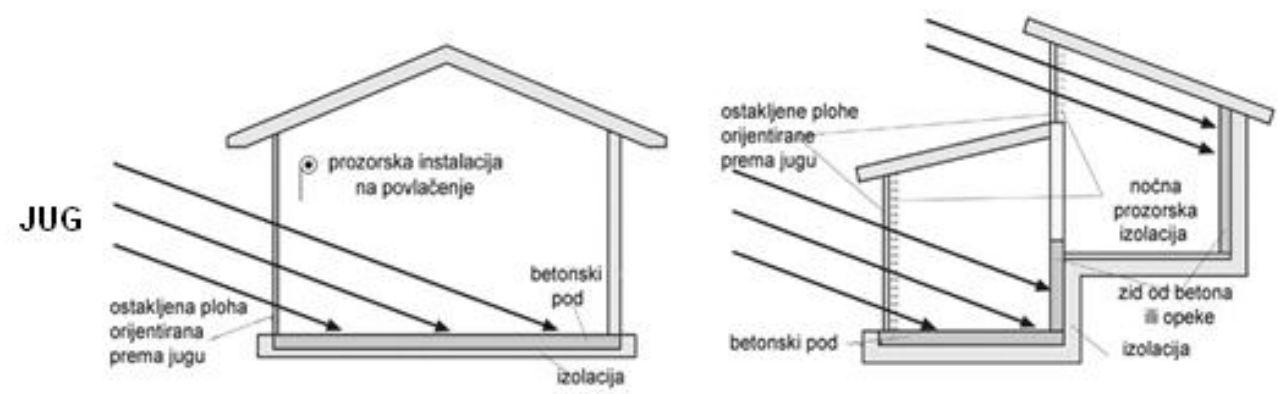

SJEVER

Slika 4 - Direktan zahvat Sunčevog zračenja

Svijetlo obojene površine održat će više svjetla unutar prostora, dok bi tamnije boje omogućile veću akumulaciju Sunčeve topline. Vrijeme kašnjenja i trajanje prijenosa topline prema van ovisi o debljini, materijalu i toplinskoj izolaciji. Konstrukcija kuće u kojoj se akumulira toplina mora biti izolirana izvana, jer inače ubrzano gubi toplinu. Toplinu gubi i kada je direktno povezana sa zemljom ili je u kontaktu sa zrakom koji je na nižoj temperaturi. Uporabom teških građevinskih materijala, odnosno dobrom toplinskom izolacijom, postiže se manja razlika u temperaturi prostorija za vrijeme noći i dana te bolja akumulacija toplinske energije za vrijeme perioda bez Sunca. Termički dobri lagani materijali (lagani beton, porozna opeka, izolatori) više će se zagrijati od teških (armirani beton, kamen) jer imaju niži toplinski kapacitet akumulacije topline. To znači da će lagani materijali lakše i brže izgubiti akumuliranu toplinu nego teški materijali.

Pod ne bi trebalo prekrivati tepisima, a treba voditi računa i o razmještaju namještaja kako bi Sunce grijalo pod, a ne tepih i namještaj.

Treba koristiti prozore s višestrukim staklom, a korisno je i prozore prekriti velikim debelim zastorima kako bi reducirali gubitak topline preko noći. Gubitak topline može se dodatno smanjiti zastorima, griljama, roletama (slika $5)$.
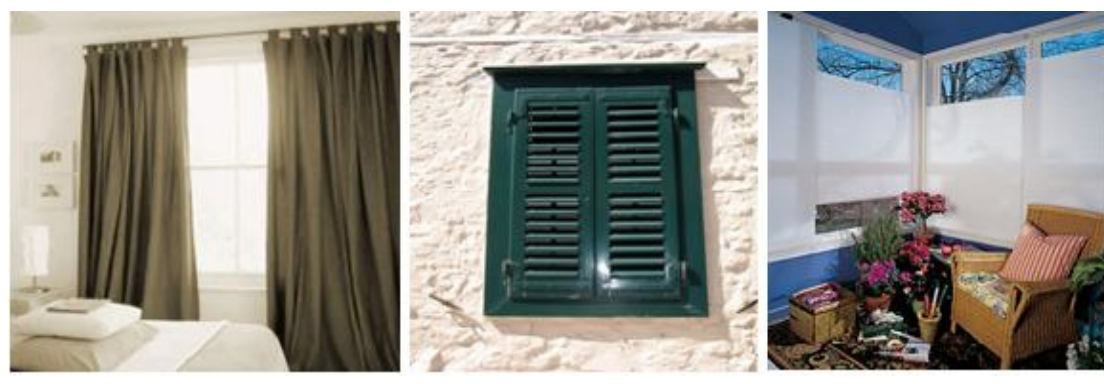

\section{Slika 5 - Elementi koji smanjuju gubitke topline- zastori, grilje, rolete}

Sljedeći primjer prikazuje obiteljsku kuću od $246 \mathrm{~m}^{2}$. Sunčeva energija se prikuplja kroz dvostruko ostakljene prozore na zidovima kuće s južne strane i kroz krovne prozore na južnoj strani krova. (slike 6 i 7).
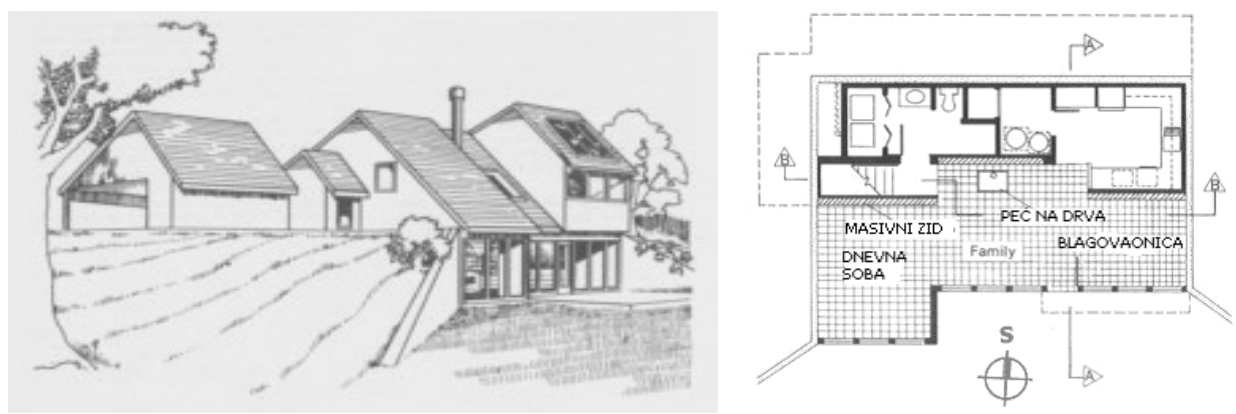

Slika 6 - Perspektiva i tlocrt obiteljske kuće koja ostvaruje direktan zahvat Sunčeve energije- Winston, Oregon (SAD) 
Površina poda prekrivena ciglastim pločicama i površina zida od betonskih blokova koje se nalaze unutar kuće, apsorbiraju Sunčevu energiju. Apsorbirana toplina se s površine provodi kroz ciglene pločice do betonskog poda te do betonskog zida gdje se pohranjuje (akumulira) (slika 7).

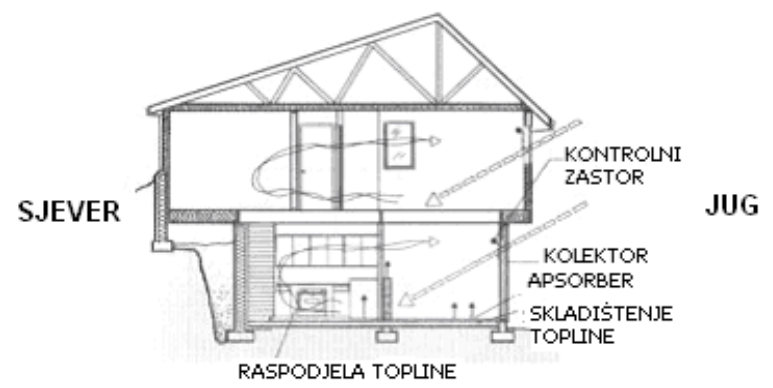

\section{Slika 7 - Presjek obiteljske kuće s raspodjelom i pohranom topline - Winston, Oregon (SAD) ${ }^{9}$}

Kada zidovi imaju sposobnost akumulacije topline, tada će nakon prekida grijanja u prostoriji biti još dugo toplo, zidovi će vraćati toplinu, odnosno bit će spriječeno naglo hlađenje prostorije. Kada Sunce zalazi, potrebno je prekriti krovne prozore drvenim izolacijskim roletama, a izolacijske zavjese se spuštaju preko prozora koji gledaju na jug. Ti pokretni uređaji kontroliraju gubitak topline. Toplinska akumulacija vanjskih konstrukcija ljeti je nepovoljna jer uzrokuje povećanje ionako visokih temperatura zraka u prostorijama. Kako bi se spriječilo zagrijavanje kuće ljeti, prozori se prekrivaju izoliranim roletama tijekom dana, a sjenila na prozorima odbijaju direktno Sunčevo zračenje. Tijekom ljetnih noći, rolete na krovnim prozorima su otvorene, a sjenila podignuta. To omogućava da toplina izlazi van. Mnogi detalji ove kuće pomažu očuvati toplinski komfor. Veći dio donjeg kata je smješten u zemlju, što je povoljno za sprječavanje prekomjernog ulaska topline u kuću ljeti. Primjeri pročelja kuća s direktnim zahvatom Sunčeve energije prikazani su na slici 8a i 8b.

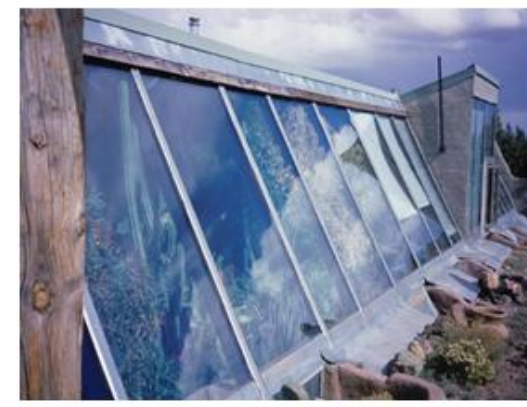

Slika 8a - Obiteljska kuća- Taylor, Arizona (SAD)

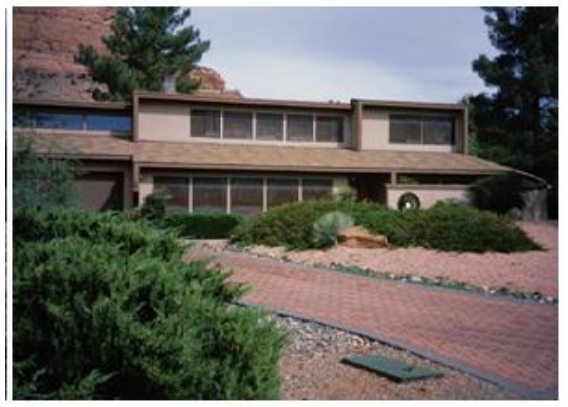

Slika 8b - Obiteljska kuća - Sedona, Arizona (SAD)

Prednosti direktnog zahvata Sunčevog zračenja:

A) jednostavan sustav

B) višestruko okno prozora je jeftin oblik solarnih kolektora

C) cjelokupni trošak može se usporediti s običnom gradnjom

D) višestruko okno prozora ne osigurava samo skupljanje topline, nego je i izvor danje svjetlosti i vizualna veza s vanjskim svijetom.

Nedostatci direktnog zahvata Sunčevog zračenja:

A) ultraljubičasto zračenje uzrokuje štete na tkaninama i umjetničkim djelima

B) manjak privatnosti gubitak topline kroz pod koji je u dodiru s tlom.

${ }^{9}$ Izvor podataka za slike 6. i 7.: http://www.oregonarchitect.com/awards_Solar.html 


\section{Trombov zid}

U mjestu Odeju u Pirinejima (Francuska) Felix Tromb je 1965. godine sagradio kuću s tamnim zidom na južnoj strani, koji je po njemu dobio naziv Trombov zid. Pomoću ovog zida Tromb je demonstrirao mogućnost djelotvorne pasivne toplinske pretvorbe Sunčevog zračenja. Trombov zid je okrenut prema Suncu i zamišljen kao pasivni solarni kolektor. Zid je istovremeno služio za apsorbiranje topline, za akumulaciju topline i kao tijelo za zagrijavanje unutrašnjih prostorija.

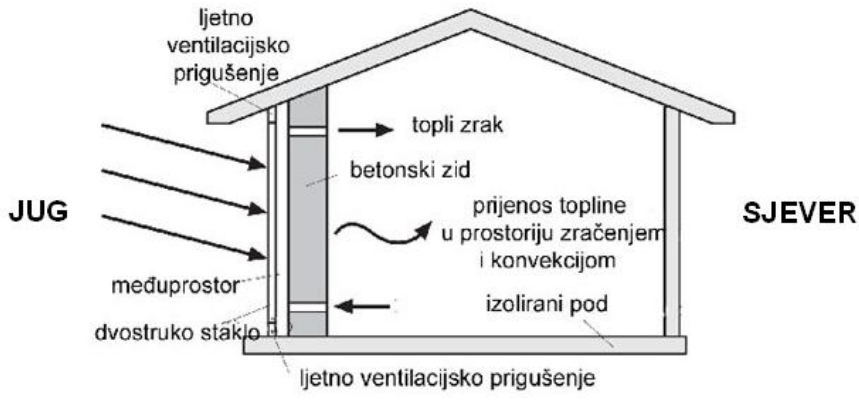

\section{Slika 9 - Trombov zid}

Trombov zid obično se izrađuje od opeke,betona ili kamena. Na udaljenosti 2-10 cm ispred zida nalazi se staklo. U praksi se koriste dvije konstrukcijske varijante Trombovog zida: bez otvora i s otvorima pri osnovi i vrhu zida. Nakon prolaska kroz staklo, Sunčevo zračenje pada na Trombov zid i zagrijava ga. Brzina prenošenja topline s vanjske na unutrašnju stranu zida zavisi od materijala od kojega je napravljen i njegove debljine. $S$ ciljem sprječavanja pretjeranog zagrijavanja prostorija ispred ili iza Trombovog zida, postavljaju se odgovarajući toplinski zastori. Općenito, otvori za prolaz topline u unutrašnjost u ljetnim mjesecima su zatvoreni, kako ne bi došlo do narušavanja toplinskog komfora. Za vrijeme ventilacijskog ciklusa Sunčeva energija se sprema u spremnik, zagrijavajući pritom zračni kanal i uzrokujući cirkulaciju kroz otvor na vrhu i dnu zida. Za vrijeme ciklusa grijanja, Trombov zid otpušta akumuliranu toplinsku energiju (slika 9).

Primjer na slici 10 je treća generacija pasivne solarne kuće s $260 \mathrm{~m}^{2}$ stambenog prostora ${ }^{10}$. Projektirao ju je i konstruirao Colorado Sunsworks. To je umjetničko djelo osmišljeno kako bi se povećao životni prostor, a stvara i prirodni osjećaj topline i ljepote. Masivni Trombovi zidovi i vertikalni zidovi osiguravaju 80\% upijene Sunčeve energije. Grijanje zahtijeva korištenje aktivne i pasivne solarne tehnologije. U kući se nalazi staklenik na dva kata i povezan je sa svim sobama, te je važan izvor topline.

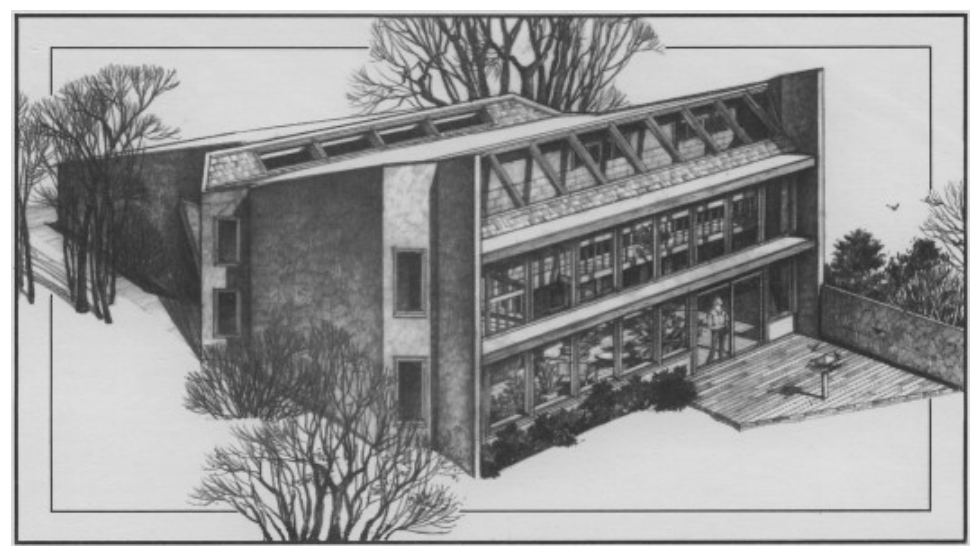

Slika 10 - Primjer kuće s Trombovim zidom - "The Sunstar Solar Home", Colorado

\footnotetext{
10 izvor podataka: http://www.dreamgreenhomes.com/plans/sunstar.htm
} 
Prvi kat: Kuhinja je središnji dio kuće te služi kao solarni izvor topline i ima pogled na staklenik. S istočne strane kuhinje je blagovaonica, a sa zapadne dnevna soba. Obje prostorije su dobro smještene i ukomponirane $s$ dobro izoliranim staklenikom koji ujedno nudi odličnu zaštitu protiv toplinskih gubitaka (slika 11).

Drugi kat: Na katu se nalaze tri velike spavaonice s prozorima otvorenim prema jugu kroz koje upijaju Sunčevu toplinu koja se akumulira u podovima i zidovima. Sve tri spavaonice dijele isti balkon (slika 11).
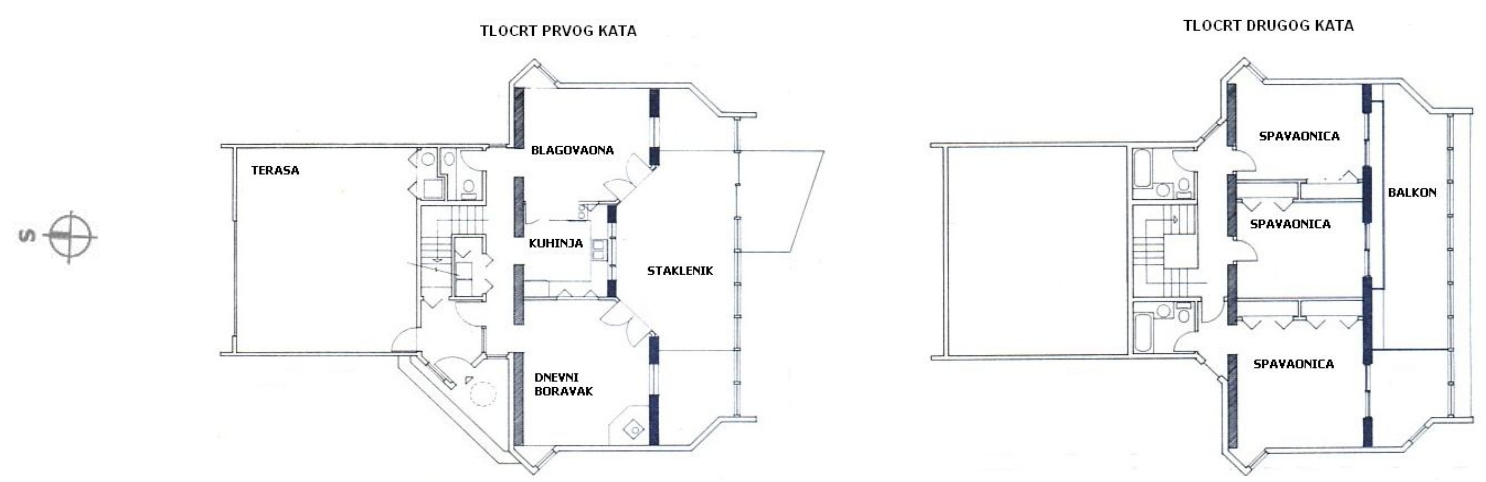

Slika 11 - Tlocrti prvog i drugog kata - "The Sunstar Solar Home", Colorado

Prednosti Trombovog zida:

A) ugodna toplina elemenata zgrade (podova, zidova, stropova)

B) bez pokretnih dijelova i, što je bitno, bez održavanja

C) relativno lako uključivanje u izgradnju strukture kao unutarnji ili vanjski zid

D) jeftini klasični građevinski materijali.

Nedostatci Trombovog zida:

A) vanjski zidovi postaju izvor gubitaka topline tijekom dužih oblačnih perioda.

Primjeri pročelja obiteljskih kuća s Trombovim zidom prikazani su na slici 12a i 12b.

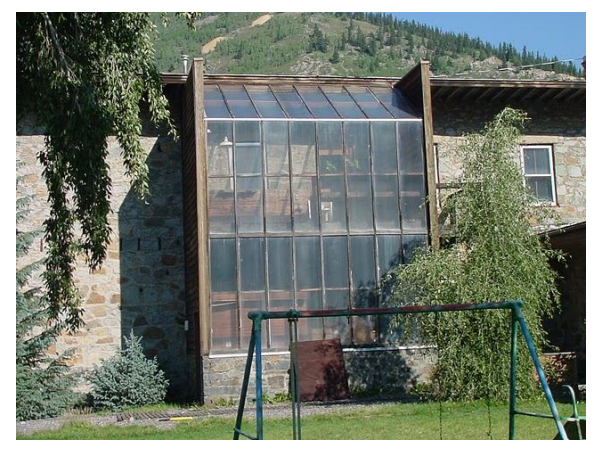

Slika 12a - Obiteljska kuća- Silverton, Colorado

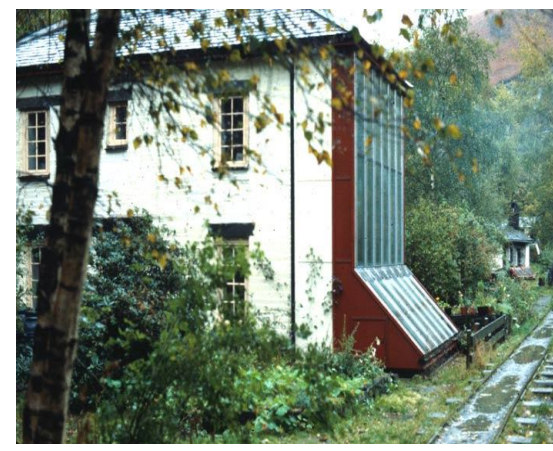

Slika 12b - Obiteljska kuća- zapadni Wales, Velika Britanija

\section{Staklenik}

Zimski vrt koristi se kao mjesto za susrete, okupljanja i druženja, ali i kao prostor za prezimljavanje i uzgoj egzotičnih biljaka. No sada je, pored estetskog aspekta, u prvom planu ekološka prihvatljivost i ekonomska isplativost, odnosno iskorištavanje Sunčeve energije i prije svega mogućnost akumulacije topline - pojavio se novi oblik stambenog i životnog prostora (slika 13). 


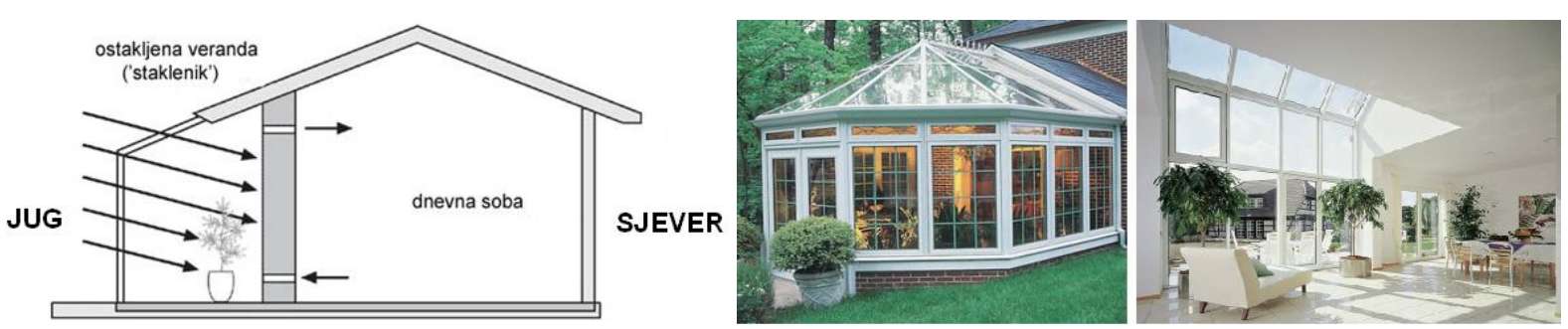

\section{Slika 13 - Staklenik - shematski presjek i dva primjera izvedbe}

Iza staklenika se nalazi masivan, tamno obojen zid koji apsorbira prispjelo Sunčevo zračenje. Noću ili zimi se otvaraju gornji i donji otvor na zidu i preko gornjeg u kuću ulazi topao zrak, a na donji izlazi hladan i kuća se zagrijava. Staklo je uglavnom nepropusno za dugovalno Sunčevo zračenje. Toplina ostaje u prostoriji.

Svaka pukotina uzrokuje ventilacijski gubitak toplinske energije. Razlog tomu je što se tijekom dana zrak unutar staklenika, zahvaljujući velikom udjelu stakla koje propušta Sunce, prilično ugrije. Navečer se dobivena energija ponovo gubi, jer staklo ima puno slabija izolacijska svojstva od, primjerice, izoliranog vanjskog zida. Izostavi li se termička izolacija, toplina glavnog dijela objekta odlazi preko zimskog vrta van. Kod potpuno ostakljenog zida ili pročelja, termičko odvajanje je naravno teže. U tom slučaju treba obratiti pažnju na zaštitu od Sunca i izdašnu ventilaciju. Danas postoje rješenja i za termički odvojene staklenike, a to su dobro izolirani i grijani zimski vrtovi, kao i oni koji se ne griju. Bez grijanja, toplina se dobiva isključivo preko Sunca, a tako dobivena toplina smanjuje energetsku potrebu cijelog objekta.

Staklenik smješten na sjevernoj strani koji nije osunčan, mora obvezno biti termički izoliran uz funkciju klimatskog ublažavanja utjecaja između vanjskog zraka i onog u prostorijama. Ravnomjerno i manje intenzivno svjetlo na sjeveru idealno je za smještaj ateljea ili radne sobe.

Uobičajeno je da se staklenik koristi za povećanje prostora i vrlo često je smješten na južnoj strani. Tijekom ljetnih dana, kada je Sunce na svojoj najvišoj točki, ovaj ugodan prostor za odmor lako se može pretvoriti u pravu malu pećnicu. Takozvani efekt staklenika može se izbjeći izdašnim zasjenjenjem i dobrim sustavom ventilacije (slika 14)

Pretpostavka za korištenje efekta staklenika jesu građevinski elementi koji imaju svojstvo povoljne akumulacije topline (masivni zidovi, kameni podovi), u protivnom postoji opasnost od pregrijavanja. Akumulacija topline Sunčevog zračenja ublažava visoke temperature i sprječava brzo hlađenje prostorije.

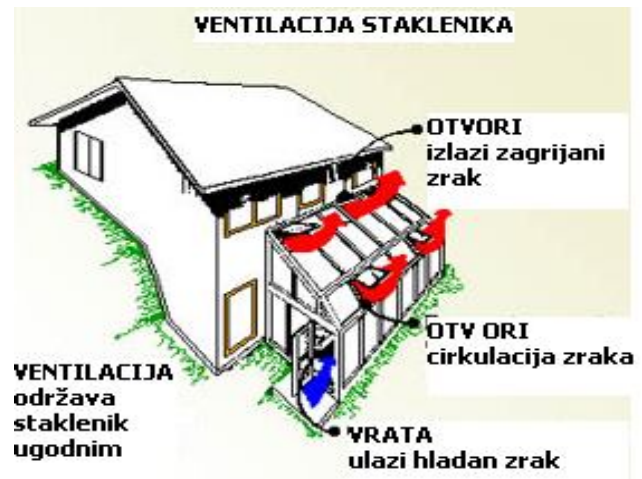

Slika 14 - Prikaz funkcioniranja ventilacije staklenika

Postoje dvije vrste ventilacije staklenika: prirodna i prinudna. Kod prirodne zrak struji preko donjih ventilacijskih otvora i onih u pročelju, zagrijava se i izlazi van preko ventilacijskih odvoda na vrhu pročelja ili u potkrovlju. Komfornija i skuplja rješenja su električno otvaranje prozora, automatizirani ventilacijski poklopci ili klime. Ostakljena južna strana ne može opstati bez zaštite koja može biti u obliku niza stabala u vrtu koja ljeti čine hladovinu, a zimi kroz svoje prorijeđene krošnje propuštaju sunce. Ipak, sama stabla nisu dovoljna. 
Najbolja zaštita protiv pregrijavanja je ona smještena s vanjske strane. Sunčeve zrake ne prodiru u kuću, već se zadržavaju vani. Dobru zaštitu pružit će rolo sjenila (slika 15), žaluzine koje su uglavnom izrađene od aluminija i druga sjenila (slika 15).
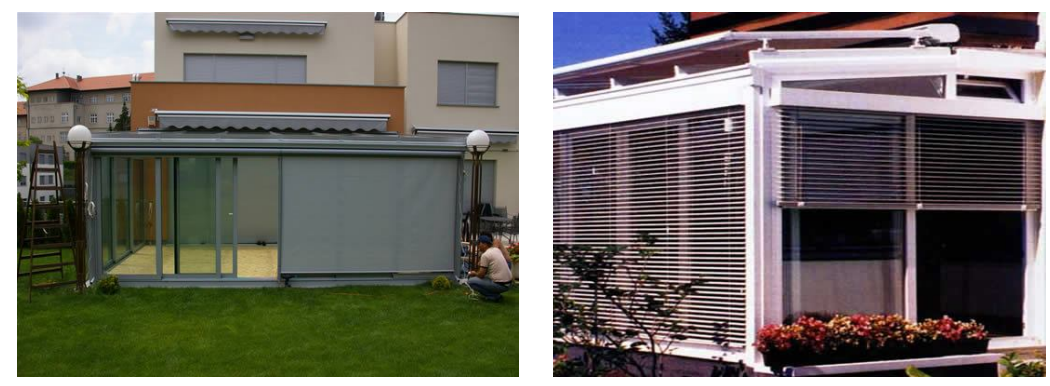

\section{Slika 15 - Elementi zaštite staklenika od sunca - rolo sjenila, žaluzine}

Osim ventilacije i zaštite od sunca, staklenici bi trebali imati i grijanje. U pravilu je najbolje upotrijebiti podno grijanje. Takvo grijanje ne mora nužno biti potrebno na južnoj strani, ali ne bi trebalo izostati na istočnoj i zapadnoj strani. Bez obzira na kojoj strani svijeta se nalazi zimski vrt, treba ga projektirati na način da bude dobitak kako za stanare, tako i za biljke!

Sljedeći primjer kuće sa staklenikom je kuća u Novom Meksiku namijenjena stanovanju dvije osobe ${ }^{11}$. Može se povećati prostor tako da prozor sa zapadne strane dnevne sobe pretvorimo u vrata i na zapadnoj strani dodamo još dodatno zatvoreno krilo kuće. Prikupljenu toplinu potrebno je akumulirati u masivnim elementima kuće (termalna masa) (slika 16).

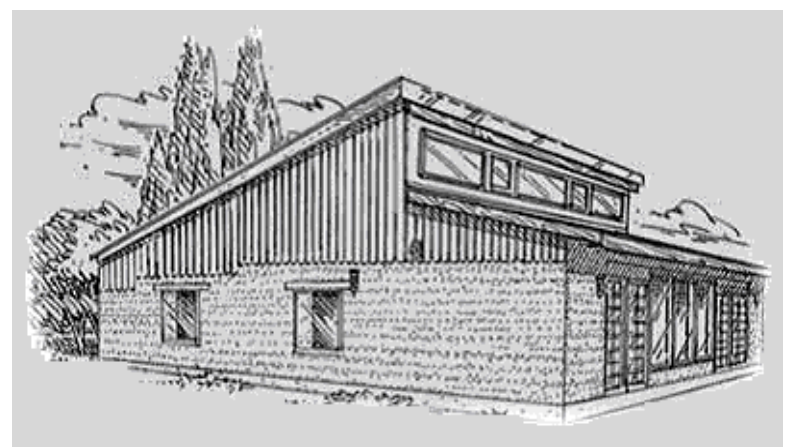

Slika 16 - Primjer kuće sa staklenikom - New Mexico (SAD)

Vlasnik može koristiti staklenik za uzgoj biljaka tijekom cijele godine. Kao i u svim staklenicima, temperatura će biti viša nego u ostalim prostorijama. Zbog toga su tu stavljena dvostruko ostakljena klizna vrata. Tijekom najhladnijeg razdoblja zime, nisko Sunce prodire kroz prozor iznad dnevnog boravka, a snop Sunčeve svjetlosti kroz dva unutarnja prozora u spavaću sobu, dobro osvjetljavajući unutrašnjost prostorije.

Veliki unos pasivne Sunčeve energije dolazi kroz južna vrata i prozore te su glavni izvor energije. Prekrivanjem staklenih površina teškim zastorima, stvara se dodatna izolacija kuće tijekom zimskih noći. Kuća ima dva masivna zida. Jedan odvaja dnevnu sobu od staklenika, drugi se nalazi između dnevne sobe i spavaće sobe, odnosno kupatila.

Tijekom zime ima pomoćno podno grijanje. Bojler koji grije kuću nalazi se u stakleniku gdje dobiva toplinu sunca. Zbog oblačnih dana, u kući je ugrađen kamin na drva koji se nalazi u dnevnoj sobi. Kada se isključi ili smanji grijanje, ili se prostor ohladi (primjerice brzim provjetravanjem), akumulirana toplina vraća se natrag u prostorije i u kraćem se vremenskom periodu održava gotovo konstantna temperatura u prostorijama putem zračenja topline s unutrašnje strane zagrijanog građevinskog elementa.

11 izvor podataka: http://www.adobebuilder.com/rammed-earth-studio-house-plan-1342.html 


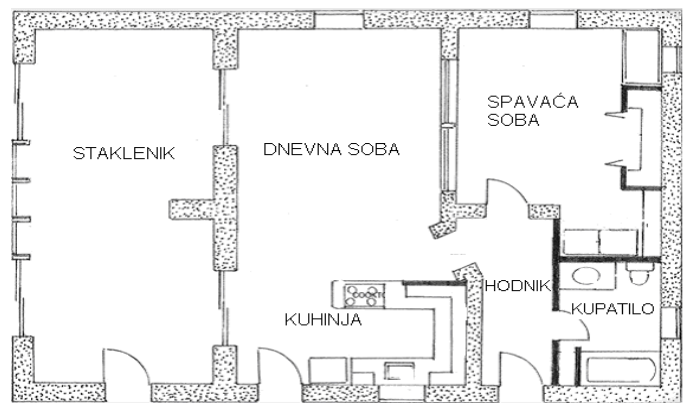

\section{Slika 17 - Tlocrt prizemlja-New Mexico (SAD)}

Primjeri južnih pročelja izvedenih obiteljskih kuća sa staklenikom prikazani su na slici 18a i 18b.

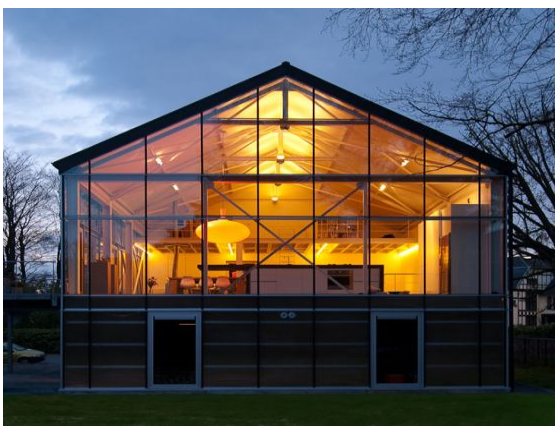

Slika 18a - Obiteljska kuća- Asse, Belgija

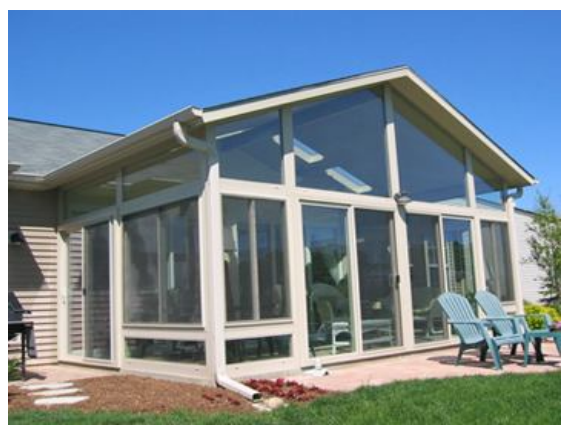

Slika 18b - Obiteljska kuća- Crystal Lake, Illinois

Prednosti staklenika:

A) velika vidljivost $i$ kontakt s okolinom

B) maksimalna svjetlost i upijanje topline

C) čvrsto i dugotrajno rješenje

D) elemente staklenika nije potrebno posebno održavati

E) štiti biljke od svih vremenskih uvjeta

Nedostatci staklenika:

A) slab izolator topline ako nije duplo postavljen

B) težak za montirati

C) lomljiv

D) osjetljiv na pojavu kondenzata, a time i na plijesan i gljivice.

\section{Zaključak}

Izvedba odgovarajuće toplinske zaštite zgrada najvažniji je element za postizanje suvremene energetske učinkovitosti. Takav način građenja postat će u skoroj budućnosti, ulaskom u EU, i kod nas obveznim standardom. Kvalitetan sloj toplinske izolacije, zabrtvljeni prozori i vrata koji osiguravaju sprječavanje gubitaka topline, sustavi za strujanje zraka koji osim prozračivanja imaju zadatak dodatno čuvati energiju u unutarnjem prostoru, te korištenje obnovljivih izvora energije za dobivanje topline (posebice Sunčeve energije) neophodni su za ostvarivanje energetske učinkovitosti u obiteljskim kućama. Tako izvedena zgrada je ugodnija, produžuje joj se vijek trajanja i značajno se doprinosi zaštiti okoliša.

U zimskom i prijelaznom razdoblju, koje je najprimjerenije za pasivno iskorištavanje Sunčeve energije, važno je da zgrada ima dovoljnu toplinsku akumulacijsku masu koja čuva akumuliranu energiju i uravnotežuje inače prevelike dnevne oscilacije temperature u prostorima klasičnih gradnji. Konstrukcije s mogućnošću velike akumulacije topline povećavaju toplinsku stabilnost prostora koje omeđuju. 
Tijekom ljetnih mjeseci unutrašnjost kuće od prekomjerne topline štite sustavi sjenila, žaluzina i tendi, a tijekom zimskih mjeseci prostor dodatno zagrijava Sunce koje prodire kroz posebno projektirana ostakljenja. Standard pasivne kuće podrazumijeva pokušaj smanjenja potrošnje energije i udovoljavanja novim globalnim zahtjevima, a istovremeno popravlja komfor stanovanja. Pruža osnovu kako bi se u novogradnjama preostala potrebna energija u cijelosti ostvarila iz obnovljivih izvora energije.

Izazovi u gradnji pasivnih solarnih kuća nalaze se u inovativnim materijalima i tehnikama, znanju, informaciji, edukaciji, novom dizajnu i procesu izgradnje, te kontroli kvalitete. lako pasivna kuća uvelike štedi energiju i novac, u jednome zasigurno nikako nije štedljiva, a to je komfor! Vlasnici i stanari u pasivnim kućama sigurno će znati cijeniti ovu veliku prednost. Zahvaljujući dobroj toplinskoj izolaciji, nema potrebe prostorije jače ili slabije zagrijavati kao što je to slučaj kod konvencionalnih kuća, jer se sve prostorije u pasivnoj kući jednako zagrijavaju, čak i one koje graniče s vanjskim hladnim zrakom. To stvara uistinu pravi ugođaj i pravi komfor u unutrašnjosti. Ustajalog ili hladnog zraka u spavaćoj sobi nema (u konvencionalnim kućama prisiljeni smo otvarati ili nagibati prozore tijekom noći), jer savršeno funkcionira sustav prozračivanja.

Ako se poboljšanje energetske učinkovitosti komponenti kao što su obodne konstrukcije zgrade i prozori dovedu do te mjere da posebni sustav ispušne topline više nije potreban, ostvaruje se ušteda koja poravnava troškove koji nastaju pri poboljšanju energetske učinkovitosti. Da bi se postigla energetska učinkovitost, moramo se prilagoditi tehnologijama korištenja obnovljivih izvora energije i novim načinima štednje energije. Trenutačno na svijetu postoji vrlo mali broj energetski učinkovitih kuća i zgrada, ali se sa svakom novom energetski učinkovitom kućom ostvaruju prijeko potrebna iskustva koja se onda mogu iskoristiti u gradnji još kvalitetnijih kuća. Ovo znanje će se sve više koristiti i uz pomoć različitih zakona u graditeljstvu. Sve će nove gradnje u vrlo skoroj budućnosti morati poštovati načela energetski učinkovite kuće.

\section{Literatura}

[1] Toth, T. 2008: MAJSTOR², Štedljivije grijanje, prva knjiga, Majstor press d.0.0., Zagreb: 82-97.

[2] Toth, T. 2009: MAJSTOR2, Moderna kuća, šesta knjiga, Majstor press d.o.o., Zagreb: 20-23.

[3] Lambić, M. 1987: Solarni uređaji, Samogradnja i termoenergetika, NIRO „Tehnička knjiga“, Beograd: 181185

[4] Zadorec, M. Josipović, D. Majer, J. 2008: Mjere uštede toplinske energije u zgradama, Građevinar 60, 5, 411-420.

[5] Prostorni plan Zajednice općina Osijek 2000.; Osijek 1985.

[6] Šimetin, V.: Građevinska fizika, GI Fakultet građevinskih znanosti Sveučilišta u Zagrebu, Zagreb 1983.

[7] Zbašnik-Senegačnik, M.: Pasivna kuća, SUN ARH d.o.o. Zagreb 2009.

Internet: http://www.scribd.com/doc/3296572/Energija-Sunevog-zraenja

http://www.scribd.com/doc/3180421/Solarna-Energija

http://www.allanstime.com/SolarHome/Trombe_Wall/index.html

http://hr.wikipedia.org/wiki/Sun\%C4\%8Deva_toplinska_energija

http://www.gradimo.hr/5266.aspx

http://www.valdez.hr/promocije/pasivne-kuce

http://www.dobrevijesti.info/svijet-oko-nas/352-prva-kua-koja-se-grije-sama

http://www.majstor.hr/teme/2002/12/pasivna_kuca/pasivna-kuca.shtml

http://www.oregonarchitect.com/awards_Solar.html

http://www.oregonarchitect.com/Residential/solar.html

http://www.usc.edu/dept/architecture/mbs/tools/thermal/controls_passolar_isol.html

http://www.azsolarcenter.org/tech-science/solar-for-consumers/living-with-the-sun-az-style.html http://www.azsolarcenter.org/solar-in-arizona/virtual-tours-galleries/passive-trombe-pv-a-more.html http://www.dreamgreenhomes.com/plans/sunstar.htm http://www.yatzer.com/1557_a_unique_greenhouse_in_belgium http://picasaweb.google.com/lh/photo/hdfC39iUTqXIVBSwNOQDtw http://www.adobebuilder.com/rammed-earth-studio-house-plan-1342.html http://www.korak.com.hr/sos.php?id_sos=318\&vijestiPage=9 http://www.scribd.com/doc/15507540/energija 